\title{
高速気流による表面付着微粒子の除去効率に及ぼす湿度の影響 ${ }^{\dagger}$
}

\author{
後藤邦彰・武部彰二・増田弘昭 \\ 京都大学工学部 化学工学教室 $^{\dagger \dagger}$
}

馬場美二

オムロン(株) ${ }^{\dagger \dagger}$

\begin{abstract}
壁面に付着した微粒子の高速気流（エアージェット）による除去操作について，壁面へ の粒子付着時および除去操作時の湿度に着目し, 粒子除去操作時の環境条件の一つである 湿度が除去効率に与える影響を検討した. その結果, 低湿度で付着した粒子は乾燥時間が 長くなるに従い除去率が低下し, 高湿度で付着した粒子では, ある乾燥時間で除去率が最 大に達した後, 低下することがわかった．また, 乾燥時間が 80 時間以上になると付着時湿 度の影響はなくなった．除去時湿度を变えて実験を行ったところ, 低湿度では除去率は低 く, 約 $67 \%$ で最大となり, それ以上の高湿度では除去率は低くなった．このような除去率 の変化は, 吸着水分子によるHamaker 定数の変化亡液膜の厚さによる表面張力の変化を 考慮にいれれば説明できることがわかった。
\end{abstract}

\section{緒 言}

電気・電子産業をはじめとして多くの分野において, 微粒子による製品の污染が問題となる，現在までは，主 に湿式洗浄により製品に付着した微粒子の除去が行われ ている.しかし，湿式法では一般に，濡れに弱い製品に は使用できない, 乾燥工程が必要となる, 洗浄液が環境 等の污染の原因となるといった問題がある.そこで，筆 者らは, 乾式で, しかも除去装置の構造が比較的簡単な 高速気流（エアージェット）による粒子除去法を取り上 げ, ジェット噴射時間, 噴射角度, ノズルー壁面間距離 等の気流操作条件か除去効率に与える影響を実験的に検 討した ${ }^{6)}$. また，噴射時間の短いジェットを連続的に噴 射して，噴射回数による除去率の変化についても検討を 行った. このジェットを連続的に噴射するパルスジェッ トを用いた除去については, 大谷ら ${ }^{9)}$ 報告している.

本研究では，壁面への粒子付着時および除去操作時の 湿度に着目し, 粒子除去操作時の環境条件の一つである 湿度が除去効率に与える影響を検討した。

$\dagger$ 1993年 7 月 15 日受理 ; 粉体工学会春期研究発表会 (京都, 1992年 5 月）にて一部発表

†† $\mathbf{0} 606-01$ 京都市左京区吉田本町

†† $\mathbf{T} 525$ 草津市西草津 $2-2-1$

\section{1. 実験装置および方法}

Fig. 1 亿除去実験装置の概略図を示す．除去実験は前 報 $^{6)}$ と同様, コンプレッサーで圧縮した空気を, ミスト 除去後減圧弁で所定圧力に調整し, ジェットノズルより 高速で除去対象面に噴射して粒子の除去を行う. ジェッ トノズルは，Fig. 2 に示した噴射口面積 $0.25 \times 10 \mathrm{~mm}^{2}$ の 2 次元スリット状ノズルを用いた。ジェット噴射条件は， ノズル内圧力 (ゲージ圧) $\Delta P_{n}$ を $10^{5} \mathrm{~Pa}$ ，噴射角度 $\theta$ を 45 度, ノズル先端と除去対称面との距離 $d$ を $10 \mathrm{~mm}$ で一 定とした. また，ノズル内圧力 $\Delta P_{n}$ が $10^{5} \mathrm{~Pa}$ の時には, ジ エット噴射時間 $t$ が 10 秒で除去率は最高値に達して一定值

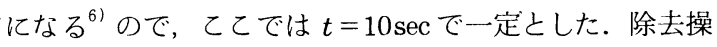
作時の室内は空調機により温度をほぼ一定に保ち（約 20 ${ }^{\circ} \mathrm{C}$ ), 主に超音波加湿器 (松下電器産業侏製, FE-05 KVE）により空気中の水分量を変えて除去時の相対湿度 $\psi$ ，を調節した。

実験では粒子を試料片（壁面）に付着させた後（除去 前），およびジェット噴射後（除去後）の粒子数をそれ ぞれ顕微鏡により計数し, それらの差を除去前の全粒子 数で割って除去率を求めた。なお，除去率は気流衝突点 近傍の 3 点 $\left(\right.$ 前報 $^{6)}$ での测定点 $1,2,3$ ) で測定し，その 平均值を除去率 $\eta$ とした。 また，粒子数計数時の測定面 積は，すべて $1 \times 1 \mathrm{~mm}^{2}$ とした.

おもな実験条件をTable 1 亿示す。試料粒子には粒子 


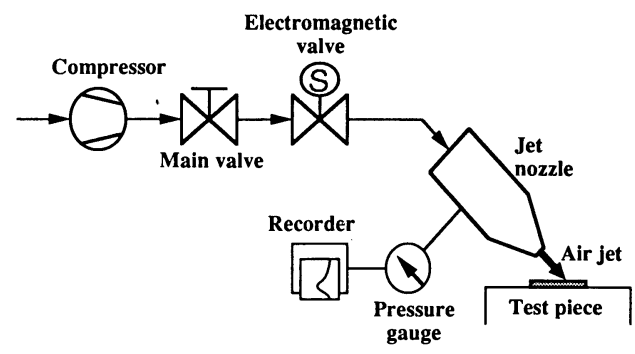

Fig. 1 Schematic diagram of experimental apparatus

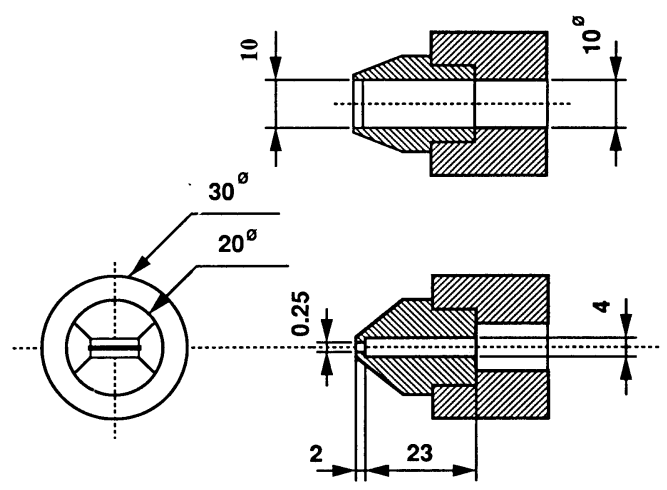

Fig. 2 Air jet nozzle

径 $3.7 \mu \mathrm{m}$ のラテックス標準粒子(Stylene/Divinylbenzene) を用い，試料片にはガラス(ほう硅酸ガラス)を用いた。

Fig. 3 は試料片へ粒子を付着させる装置である．ラテッ クス標準粒子は界面活性剂を含有した液中に分散させた 状態で保存されているので，ネブライザーで噴霧してエ アロゾル化した後, バッファー容器で粒子を加熱し乾燥 させた. 気流中の水分はシリカゲルを充填した拡散乾燥 器で除去し，インパクターを用いて慣性衝突により粒子 を壁面任付着させた。インパクターはジェット径 $9 \mathrm{~mm}$ で，気流流速は約 $6 \mathrm{~m} / \mathrm{s}$ ，で一定とした。付着操作時にデ ジタル温湿度計を用いてインパクター内衝突板下流での 気体湿度を測定し，乙れを粒子付着時湿度 $\psi_{d}$ とした。 こ の付着時湿度はバッファー容器での加熱温度および拡散 乾燥器の長さを変えることにより変化させた。除去時湿 度 $\psi_{r}$ の影響を検討する時には, 付着条件はバッファー容器 の壁面温度約 $60^{\circ} \mathrm{C}$, 拡散乾燥器長さ $66 \mathrm{~cm}$ (気流平均滞留 時間約 0.23 秒) で一定とした。一般に，慣性衝突により 壁面に付着した粒子の個数は，気流の衝突点を中心に半 径方向に分布を持つが，本実験での測定点である気流衝 突点近傍では粒子数に顕著な差は見られず，ほぼ均一な 付着状態を確認した。 また，付着粒子数は，1つの測定 面内で約 200 個となるよう, 粒子付着時間を調節した.

粒子付着後, 光学顕微鏡を用いて各測定面での粒子数
Table 1 Experimental conditions
Wall

Particle

Particle size

Nozzle pressure

Jet impinging angle

Jet-wall distance

Jet duration time

Relative humidity (deposition)

Relative humidity (removal)

Drying time in desiccator
Glass

Stylene/divinylbenzene

$D_{p} \quad 3.7 \mu \mathrm{m}$

$\Delta P_{n} \quad 10 \mathrm{~Pa}$

$\theta \quad 45 \mathrm{deg}$

d $10 \mathrm{~mm}$

$t \quad 10 \mathrm{~s}$

$\psi_{d} \quad 52 \sim 74 \%$

$\psi_{\text {r }} \quad 55 \sim 82 \%$

$t_{d} \quad 1 \sim 180 \mathrm{hr}$

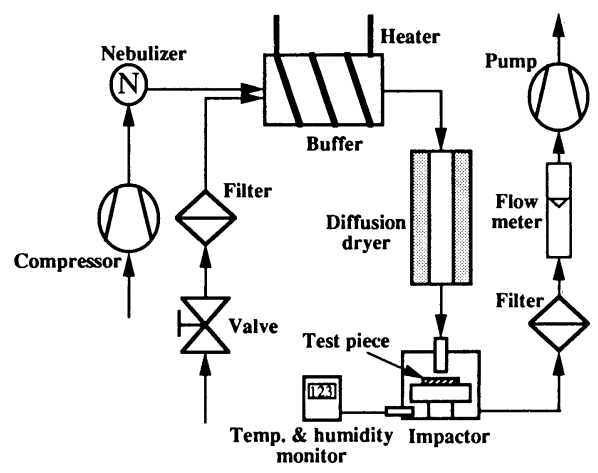

Fig.3 Apparatus for preparing a particle deposited test piece

を計数し，デシケータ内で乾燥させた．試料片をデシケ 一夕内に入れるために蓋の開閉を行った後, デシケータ 内が定常的な湿度（約 $15 \%$ ）に達するまでには約 15 分を 要する．乙のため, 乾燥時間は一定湿度中での乾燥と見 なせるように最低 1 時間とした。

\section{2. 実験結果および考察}

Fig. 4 に，付着時の湿度をパラメータとして，デシケ 一夕内での乾燥時間を変えて除去実験を行った結果を示 す. 各実験での付着時の湿度は土1.5\%以内の精度で調節 した。 また，除去時の湿度 $\psi_{r}$ は $59 \%$ で一定とした，付着 時の湿度が最む低い $\psi_{d}=55 \%$ では, 乾燥時間が長くなる 亿従い除去率は低下し，5時間を越えると約 $10 \%$ で一定 値となる. $\psi_{d}=58 \%$ では，乾燥時間 20 時間近傍までは除 去率の低下は小さく，70～80\%の高い除去率が得られ， 乾燥時間が 20 時間を越えると急激に低下をはじめる． 60 時間を越えると $\psi_{d}=55 \%$ での值と等しく，一定值となる. $\psi_{d}=64,72 \%$ では，それぞれ 3 時間， 6 時間近傍までは 乾燥時間が長くなるに従い除去率は高くなるが，その後， 急激低下する．すなわ 度で付着させた場合には乾燥時間が長くなるにつれて除 


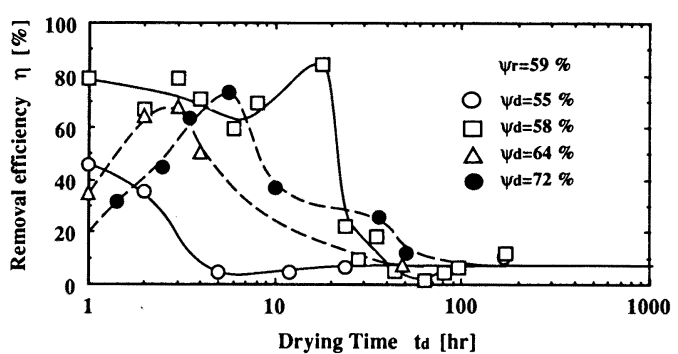

Fig.4 Effect of drying time on the removal efficiency

去率は減少し，（2）除去時湿度以上で付着させたときに ははじめ除去率は向上し，ある乾燥時間で最高值となっ た後低下をはじめる。また，（3）乾燥時間が80時間を越 えると付着時の湿度 $\psi_{d}$ は除去効率に影響しなくなるて とがわかる。乙れらの結果から，常温 $\left(25^{\circ} \mathrm{C}\right)$ で湿度 $60 \%$ 前後の通常の雾囲気中で除去を行う時には，比較的低湿 度の雾囲気中で付着した粒子は付着後直ちに除去した方 か除去効率は良く，高湿度で付着した粒子はある程度乾 燥した方が除去効果は高くなるといえる.

除去時の湿度 $\psi_{r}$ を変えて除去実験を行った結果を Fig. 5 に示す.乙こでは，付着時の湿度の影響がでない ように, Fig. 4 の結果に従って粒子付着後テストピース をデシケータ内で 100 時間以上乾燥させた. 乾燥後, 調 整した除去環境中に移し 2 分以上放置した後, 除去実験 を行った。除去率は低湿度では低く，湿度が増加するに つれて急激に増加する。除去時湿度 $\psi$ r が約 $67 \%$ で除去 率は最大となり，それ以上の湿度では低下する，乙の図 から，除去操作の環境条件である除去時湿度 $\psi$ r を調節 することにより，粉体付着操作時の湿度にかかわらず除 去率を向上できることがわかる，なお，乙の傾向は，本 実験で用いたガラス片だけでなく高分子系执よび金属系 の試料片に扔いても見られた。乙れら試料片の材質を変 えた実験結果は別報で報告する．また，乾燥後，除去環 境にセットした後の放置時間を变えて実験を行ったが, 放置時間が 1 分以上あれば除去率に影響しないととを確 認した。すなわち，Fig.5の各実験結果は，除去環境中 での平衡値であると考えられる.

湿度により除去率が变化する原因として，粒子一壁面 間付着力に対して粒子および壁面上に存在する水分子の 及ぼす影響が考えられる．湿度が低く，水分子の影響が ない場合にはvan der Waals 力は真空中の值で近似でき， 水の存在するときよりあ大きな付着力となる．また，湿 度か高くなり粒子一壁面間に液膜が形成されると, 湿度 の增加に伴い液架橋力が増加し, 付着力が増加すること が報告されている1．乙のことから，除去率は低湿度で は主にvan der Waals 力の増加により低下し，高湿度で

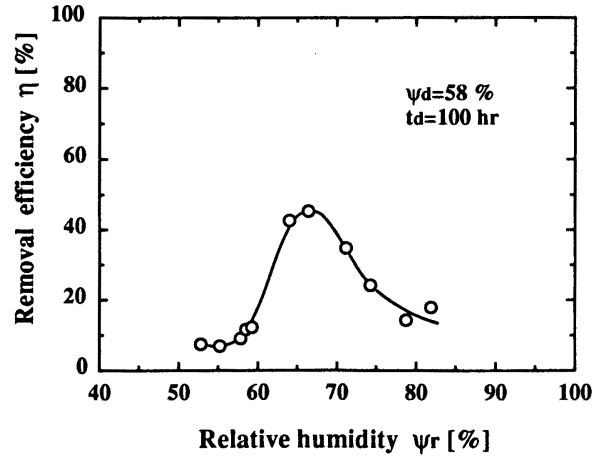

Fig.5 Effect of relative humidity on the removal efficiency

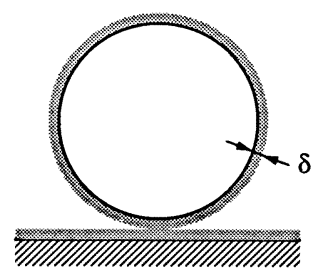

a) low humidity

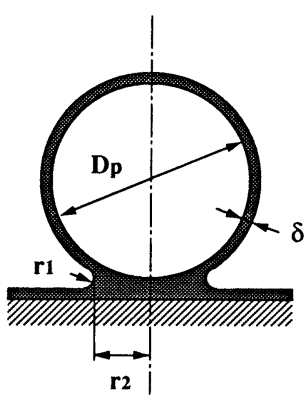

b) high humidity
Fig. 6. Model showing water adsorption

は液架橋力の増加により低下したと考えられる．低湿度 では，一般に，粒子抢よび壁表面は水分子が吸着した状 態にあり，数分子層以下の吸着分子層を形成していると 考えられる(Fig. 6-a)．試料壁面であるガラス表面上で の水の吸着層厚さ $\delta$ の相対湿度による变化は近沢ら ${ }^{11}$ に より示されており，ててではHalseyの式 ${ }^{12)}$ を変形した 次式により近似する.

$$
\begin{gathered}
\ln \psi=-\frac{k}{R T \theta_{w}^{r}} \\
\theta_{w}=v / v_{m} \\
\text { ここで, } v=S \delta \text { とおくと, } \\
\ln \psi=-\frac{K_{h}}{\delta^{r}} \\
K_{h}=\frac{k v_{m}}{R T S}=1.48 \times 10^{-17} \\
r=1.81
\end{gathered}
$$

係数掞よびべき指数の決定に用いた結果と近似曲線を Fig. 7 亿示す. 近似した曲線はプロット点とよく一致する. また，乙の図から本実験範囲内では最む低い湿度におい ても約 $0.5 \mathrm{~nm}$ (約 1.7 分子) 以上の水分子か吸着するてと がわかる. この状態では, 吸着水分子層はバルクの水と は異なり粒子 - 壁面間付着力として液架橋力は働かない 


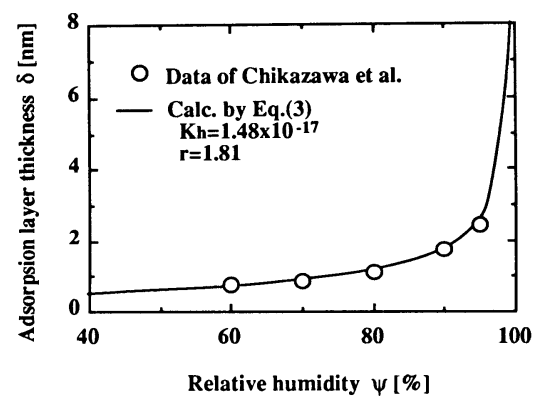

Fig.7 Approximation of adsoption-layer thickness

が, van der Waals力抢よび静電気力が㗢くと考えられ る. こてではvan der Waals 力 $F_{v}$ のみを考え, 静電気 力は無視すると，粒子一壁面間付着力 $F_{d}$ は次式で与え られる゙。.

$$
\begin{aligned}
& F_{d}=F_{v}=\frac{A D_{p}}{12 z_{0}^{2}}\left(1+\frac{A^{2} k_{p}^{2} D_{p}}{108 z_{0}^{7}}\right) \\
& k_{p}=\frac{1-\nu_{p}^{2}}{E_{p}}+\frac{1-\nu_{w}^{2}}{E_{w}} \\
& z_{0}=4 \times 10^{-10} \\
& E_{w}=7.5 \times 10^{10}(\text { ガラス })^{7)} \\
& E_{p}=0.38 \times 10^{10}(\text { ポリスチレン })^{71}
\end{aligned}
$$

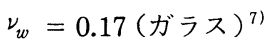

$$
\begin{aligned}
& \nu_{p}=0.34 \text { (ポリスチレン) }{ }^{7)}
\end{aligned}
$$

水分の存在によりEq.(4)中で主にHamaker 定数 $A$ が変化 し，乾燥した空気中と液中に対して，それぞれ次式で近 似できる ${ }^{11)}$.

$$
\begin{array}{ll}
A=\sqrt{A_{p} \cdot A_{w}} & \text { (空気中) } \\
A=\left(\sqrt{A_{p}}-\sqrt{A_{l}}\right)\left(\sqrt{A_{w}}-\sqrt{A_{l}}\right) & \text { (液中) }
\end{array}
$$

しかし, 上式上り水分による付着力の变化を考えると, 空気中の值から液中の值にステップ状に変化することに なるので，実験結果で見られたような湿度に対する連続 的な除去率の変化を表すてとができない，そこで，粒子 - 壁面間の媒体 (水分子+空気) のHamaker 定数が湿度 によって連続的に変化する吸着水分子層に依存すると考 える. 吸着層が存在する場合のHamaker 定数は次式で 与えられる ${ }^{10)}$.

$$
\begin{aligned}
& A=\left(\sqrt{A_{p}}-\sqrt{A_{j}}\right)\left(\sqrt{A_{w}}-\sqrt{A_{j}}\right) \\
& A_{j}=\left[K_{a} \sqrt{A_{a}}+\left(1-K_{a}\right) \sqrt{A_{m}}\right]^{2} \\
& K_{a}=2 \delta K_{a 0} / z_{0}
\end{aligned}
$$

ここで, $A_{a}$ は吸着質の Hamaker 定数, $A_{m}$ は媒体の Hamaker 定数を表す. 本実験では媒体は空気で, 吸着 質は水分子であるので, Eqs. (8), (9) は $K_{a}=0$ の時Eq. (6) と等しくなり， $K_{a}=1$ の時 Eq.(7) と等しくなる.すなわ ち, $A_{m}=0$ である. よって, 粒子-壁面間の Ha maker 定数は次式で表される.

$$
A=\left(\sqrt{A_{p}}-K_{a} \sqrt{A_{l}}\right)\left(\sqrt{A_{w}}-K_{a} \sqrt{A_{l}}\right)
$$

Eq. (10) 中の $K_{a 0}$ は 2 物体間での吸着質と媒質の体積割 合を， $2 \delta / z_{0}$ は吸着層厚さと 2 物体間表面距離の比をそ れぞれ表わす. 吸着水分子が存在しない場合には $K_{a 0}=0$ で, $K_{a}=0$ である. 水分子が存在する場合に吸着水分子 がバルクの水と同じと考えると $K_{a 0}=1$ で一定となる. $z_{0}$ を $4 \AA$ 之すると本実験範囲内 $(\delta \geqq 5 \AA)$ では $2 \delta / z_{0}$ は 1 以 上となり， $K_{a}$ は 1 以上となる. そてで, $K_{a}$ は吸着水分子 層厚さ $\delta$ 亿依存するとし， $\delta$ の一次関数で与える. 水分 子層厚さ $\delta=0$ の時 $K_{a}=0$ とし, 吸着水膜が液体的物性 を具備し毛管凝縮が可能となる時の液膜の厚みは 2.9 〜 $3.7 \mathrm{~nm}$ とされている ${ }^{2)}$ ので, 粒子一壁間の液膜厚さ $2 \times$ $\delta$ が $3.5 \mathrm{~nm}$ のとき $K_{a}=1$ として, 次式で与えた.

$$
\begin{gathered}
K_{a}=\left(1.75 \times 10^{-9}\right)^{-1} \delta \\
0 \leqq K_{a} \leqq 1
\end{gathered}
$$

試料粒子表面への吸着水分子層厚さすEq.(3)で与えられ るとすると, Eqs. (3)〜 (6), (9)〜 (12)を用いて, 湿度 $\psi_{r}$ による付着力 $F_{d}$ の変化を計算することができる，除去実 験結果は除去率で表されているので，計算された付着力 $F_{d}$ を基に除去率の計算值 $\eta_{c a l}$ を求める. Fig. 8 亿示すよ うに，前述の付着力 $F_{d}$ をその平均值として粒子一壁面 間の付着力に分布を与える. なお，付着力分布 $f_{a d}$ は次 式のように対数正規分布を仮定した.

$$
f_{a d}=\frac{1}{\ln \sigma_{g} \cdot \sqrt{2 \pi}} \exp \left\{-\frac{\left(\ln F-\ln F_{d}\right)^{2}}{2 \ln ^{2} \sigma_{g}}\right\}
$$

いま，除去力を $F_{r}$ とすると，除去率 $\eta_{c a l}$ は付着力分布よ り次式で計算できる.

$$
\eta_{c a l}=\int_{0}^{F_{r}} f_{a d} d F
$$

Eqs.(13), (14)より, 湿度による付着力 $F_{d}$ の変化加ら除去 率の変化を計算するてとができる. $\ln \sigma_{g}$ をパラメータと して湿度による除去率の变化を計算した結果を Fig. 9 亿 示す. ここで， $F_{r}$ は，液架橋が形成されないと考えられ る湿度 $\psi_{r}=60 \%$ での実験結果より $\eta_{c a l}=12 \%$ となるように 各 $\ln \sigma_{g}$ にいて決定した。 また, 計算には以下のHamaker 定数を用いた.

$$
\begin{array}{ll}
A_{w}=1.6 \times 10^{-19} \quad\left(\text { ガラス }: \mathrm{SiO}_{2}\right)^{10)} \\
A_{p}=1.2 \times 10^{-19} \quad(\text { ポリスチレン })^{10)} \\
\left.A_{l}=4.8 \times 10^{-20} \quad \text { (水) }\right)^{10)}
\end{array}
$$

湿度 $\psi_{r}$ が $67 \%$ 以下の範井では, $\ln \sigma_{g}=0.2$ として計算し た結果と実験結果はほぼ一致する。乙れより，低湿度で の除去率の変化は, 吸着水分による Ha maker定数の変化 で説明ができることがわかる．しかし，計算結果は湿度 $\psi_{r}$ が $67 \%$ 以上であ右上がりの曲線となり，実験結果の 最大值を持つ傾向とは一致しない，乙れは，高湿度にお いて形成される液膜による液架橋力を考慮していないた めであると考えられる. 


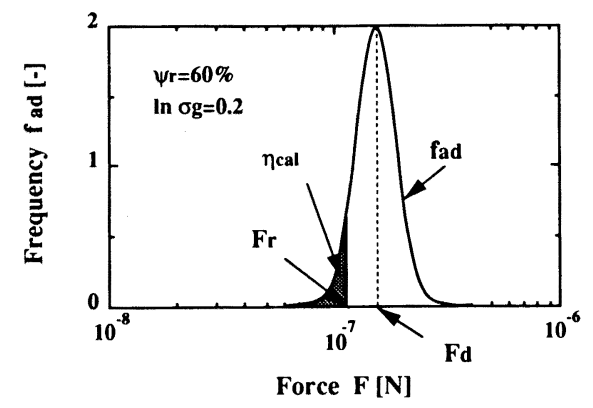

Fig. 8 Schematic diagram showing the change of calculated removal efficiency depending on adhesive force

粒子と壁の接触点近傍では, 飽和蒸気圧以下であって あ湿度がある程度高ければケルビン効果により水分が凝 縮し，液膜を形成するてとが知られている。 ての液膜に より，粒子一壁面間には液架橋力が働くと考えられる. 本実験では粒子, 試料片表面上の不純物(界面活性剂等) や粒子付着・除去操作環境での空気中不純物を除去して いないので，凝縮液中には溶解性不純物が含まれると考 えられる，そてで，ケルビン式は，向阪ら ${ }^{4,5)}$ とり等径 2 球間の液架橋に対して示された式(Appendix参照)を 用いた。乙の式は等径の 2 球間に対して導出されている ので, $r_{0}$ を次式で定義する換算粒径 $d_{e}$ を用いて, 球一平 板間 $\left(d_{1}=D_{p}, d_{2}=\infty\right)$ に変換した.

$$
d_{e}=\frac{d_{1} d_{2}}{d_{1}+d_{2}}=r_{0}
$$

向阪らの式および Eq. (15) を用いると, 除去時湿度 $\psi_{r}$ の 時の液膜半径 $r_{1}$ 打よび液橋半径 $r_{2}$ が求められる. 前述 の上うに液膜厚さが $2.9 \sim 3.7 \mathrm{~nm}$ で架橋が形成されるこ とから, 液膜厚さ $2 \times\left(\delta+r_{1}\right)$ が $3.5 \mathrm{~nm}$ 以上となる湿度 で液架橋が形成されると仮定した。乙れらの值から，次 式で表されるLaplace-Young $の$ 式 ${ }^{8)}$ を用いて液架橋力 $F_{w}$ を求めた。

$$
\begin{aligned}
& F_{w}=2 \pi r_{2} r \\
& \quad+\pi r_{2}^{2} r\left\{\left(1 / r_{1}\right)-\left(1 / r_{2}\right)\right\}
\end{aligned}
$$

粒子一壁面間付着力 $F_{d}$ は, 液架橋力 $F_{w}$ 之 van der Waals 力 $F_{v}$ の和として, 次式で与えられる.

$$
F_{d}=F_{w}+F_{v}
$$

先之同様，Eq.(17) で与えられる付着力を付着力の平均 值として付着力分布を仮定し，不純物の分子数 $N_{s}$ をパラ メータとして除去率を計算した結果をFig.10に示す。計 算では, $\ln \sigma_{g}$ はFig.9 で低湿度での実験結果よよく一致 した 0.2 とし，除去力 $F_{r}$ は Fig. 9 と同じ值 $\left(1.1 \times 10^{-6}\right)$ を 用いた. Eq. (16) を基にして計算した結果は図中の破線 で表した。液膜が形成される湿度までは，Fig.9 と同様， 除去率は增加するが，液膜を形成すると除去率は計算で

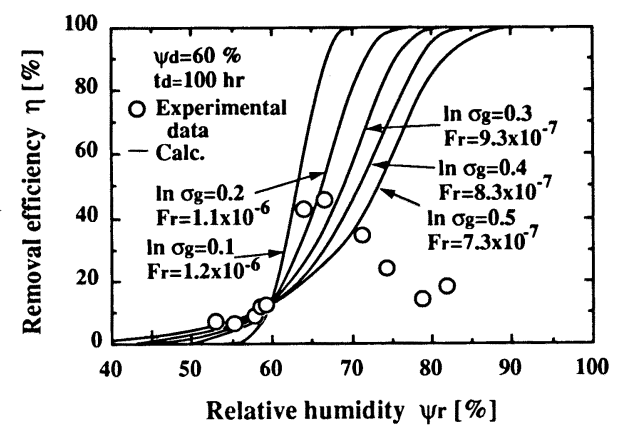

Fig. 9 Calculated removal efficiency as a function of relative humidity (van der Waals)

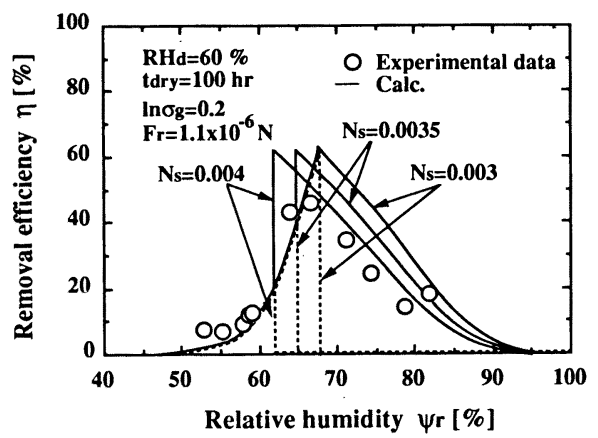

Fig.10 Calculated removal efficiency as a function of relative humidity

(van der Waals + liquid bridge)

はほぼ 0 となり，実験結果とは全く異なる。乙れは，厚 みが薄いときには液架橋の表面張力 $r$ はバルクの水の值 よりあ小さいととを考慮していないためであると考えら れる．多孔質ガラスを用いた実験結果 ${ }^{2)}$ より，液膜厚さ による表面張力の変化を次式で近似する.

$$
\begin{aligned}
\frac{r}{r_{0}} & =0.17 \times\left(\delta+r_{1}\right)+0.32 \\
r_{0} & =7.3 \times 10^{-2}
\end{aligned}
$$

上式を Eq. (16) に代入し，除去率を計算した結果がFig. 10 中の実線である. 計算結果は, 不純物の分子数 $N_{s}=$ $0.0035\left[\mathrm{~mol} \cdot \mathrm{m}^{-3}\right]$ とすると, 高湿度での除去率は計算値 の方が $10 \%$ 程度高いが除去率の変化傾向は良く一致し， 除去率が最大となる湿度むほぼ一致する。乙の図から， 高湿度での除去率の減少は液架橋の形成による付着力の 増加が原因であり，その変化は液膜厚さによって表面張 力が線形に変化すると仮定すれば説明できるととがわか る.また，Fig, 9 亿示したvan der Waals 力の影響と併 せて考えると，除去率が最大值を持つのは吸着水分によ るvan der Waals 力の低下と液架橋の表面張力がバルク の水のそれより小さいことによると考えられる．不純物 
の分子数 $N_{s}$ を変えて計算を行った結果から, 不純物量 が低いほじ液膜が形成される湿度は高く，除去率が最大 となる湿度は高くなる. このてとから, 除去前および除去 時での粒子, 壁表面上の不純物量を減らせば, より高い湿 度まで液膜は形成されず, van der Waals 力の低下により Fig. 9 に示したような高い除去率が得られることが予想 される.

粒子の付着時および乾燥時にもこてで示した吸着水分 子量による van der Waals力の变化と液架橋力の変化が 影響すると考えると, Fig. 4 亿示した乾燥時間による除 去率の変化む定性的に説明ができる.すなわち, 高湿度 で粒子が付着した時には液架橋力とvan der Waals力が 付着力として働くと考えられる. 乾燥に伴い液膜は小さ くなり, 液架橋力が小さくなるために付着力が減少し， 除去率は高くなる．さらに乾燥すると液膜は消失し吸着 水分子の状態となり, 水分子が減少するにつれ van der Waals 力が液中の值から空気中の值に近づくため, 付着 力は增加し除去率は低くなると考えられる. 低湿度で付 着した時には, 付着時から水分子は液膜を形成せずvan der Waals 力が支配的であるので, 乾燥に伴い付着力が 増加し除去率は低下すると考えられる。

\section{結言}

壁面への粒子付着時の湿度および除去操作時の湿度に 着目し, 高速気流による粒子除去効率に及ぼす湿度の影 響を検討した。そこの結果，以下の知見が得られた。

1）低湿度で付着した粒子は, 乾燥時間が長くなるに 従い，除去率が低下する．高湿度で付着した粒子では， ある乾燥時間で除去率が最大に達した後, 低下する. 乾 燥時間が 80 時間以上になると付着時湿度の影響は見られ なくなる。

2）除去操作時の湿度を変えて実験を行ったとてろ, 低湿度では除去率は低く，約67\%で最大となり，それ以 上の高湿度では除去率は低くなるてとがわかった。

3）低湿度での除去率の変化は, 吸着水分子による Hamaker 定数の変化を考慮することにより説明ができ る. また, 高湿度での変化は液膜の厚さによる表面張力 の变化を考慮にいれれば, 液架橋力の式で説明できるこ とがわかった. 従って, 上記1),2)は一般性のある結果 之言える.

\section{Appendix}

ケルビン効果を表す式には，以下に示す向阪 $ら^{4,5}$ 亿より等径 2 球間の液架橋に対して示された式を用いた。

$$
\psi_{r}=\left(1-\gamma_{s}\right) \exp \left(-\frac{M_{w} \sigma}{R T \rho_{l}} \cdot \frac{d s}{d v_{w}}\right)
$$

$$
\begin{gathered}
r_{s}=\frac{\mathrm{i} M_{w}}{\rho_{w}} /\left(\frac{3 v_{w}}{4 \pi N_{s} r_{0}^{3}}-\frac{M_{s}}{\rho_{s}}+\frac{\mathrm{i} M_{w}}{\rho_{w}}\right) \\
\quad 0 \leqq r \leqq 1 \\
v=2 \pi r_{0}^{3} R_{1}^{2}\{1+H / 2- \\
\left.A_{s} \sqrt{\left(1+R_{1}\right)^{2}-(1+H / 2)^{2}}-H^{2}(H+6) /\left(24 R_{1}^{2}\right)\right\} \\
\frac{d s}{d v}=\frac{2}{r_{0}} \times \frac{\left(2 R_{1}^{2}+3 R_{1}-H^{2} / 4-H\right) A_{s}}{-R_{1}\left(3 R_{1}^{2}+5 R_{1}-H^{2} / 2-2 H\right) A_{s}} \\
\frac{-\sqrt{\left(1+R_{1}\right)^{2}-(1+H / 2)^{2}}}{+\sqrt{\left(1+R_{1}\right)^{2}-(1+H / 2)^{2}}} \\
\frac{\times R_{1}\left(2 R_{1}+3\right)(1+H / 2) /\left(R_{1}+1\right)^{2}}{\times R_{1}\left(2+3 R_{1}\right)(1+H / 2) /\left(R_{1}+1\right)} \\
A_{s} \equiv \sin ^{-1}\left\{(1+H / 2) /\left(1+R_{1}\right)\right\}
\end{gathered}
$$

Eq.(A-2) 中で, 不純物濃度は薄いとして $M_{s} / \rho_{s}=0$ とした。 また, $i$ は溶質 (不純物) の種類, 濃度により異なるが, ここ では $2^{4)}$ とした。 $R_{1}$ は次式で定義される無次元液膜半径であ る.

$$
R_{1}=r_{1} / r_{0}
$$

$r_{1}$ は F ig. 6 に示した凝縮液膜半径を表す. 凝縮液膜を粒子およ び壁面に接する円弧で近似すると, 半径 $r_{1}, r_{2}$ の間には次式が 成立する。

$$
\frac{r_{2}}{r_{0}}=\sqrt{\left(1+r_{1}\right)^{2}-(1+H / 2)^{2}}-R_{1}
$$

以上の式により，除去時湿度 $\psi$ rにおいて形成される凝縮液膜 半径 $r_{1}$ および液膜半径 $r_{2}$ を計算した。

[ 謝 辞 ] 本研究において多大なるご協力と貴重なご意見 を頂きましたオムロン株式会社右近忠郎氏, 伊藤貞則氏, 西村 定氏に謝意を表します。

\section{Nomenclature}

$A=$ Hamaker constant between particle and wall

$A_{s}=$ Hamaker constant of adsorbate

$A_{i}=$ Hamaker constant of interface with adsorbed layer

$A_{l}=$ Hamaker constant of water

$A_{m}=$ Hamaker constant of media

$A_{p}=$ Hamaker constant of particle

$A_{w}=$ Hamaker constant of wall

$D_{p}=$ particle diameter

$d=$ jet-wall distance

$d_{1}, d_{2}=$ diameter

$d_{e}=$ equivalent diameter

$E_{p}=$ Young's modulus of particle

$\left[\mathrm{N} \cdot \mathrm{m}^{-2}\right]$

$E_{w}=$ Young's modulus of wall

$\left[\mathrm{N} \cdot \mathrm{m}^{-2}\right]$

$F=$ adhesive force between particle and wall [N]

$F_{d}=$ average adhesive force

$F_{r}=$ removal force

$F_{v}=$ van der Waals force

$F_{w}=$ liquid bridgeing force 


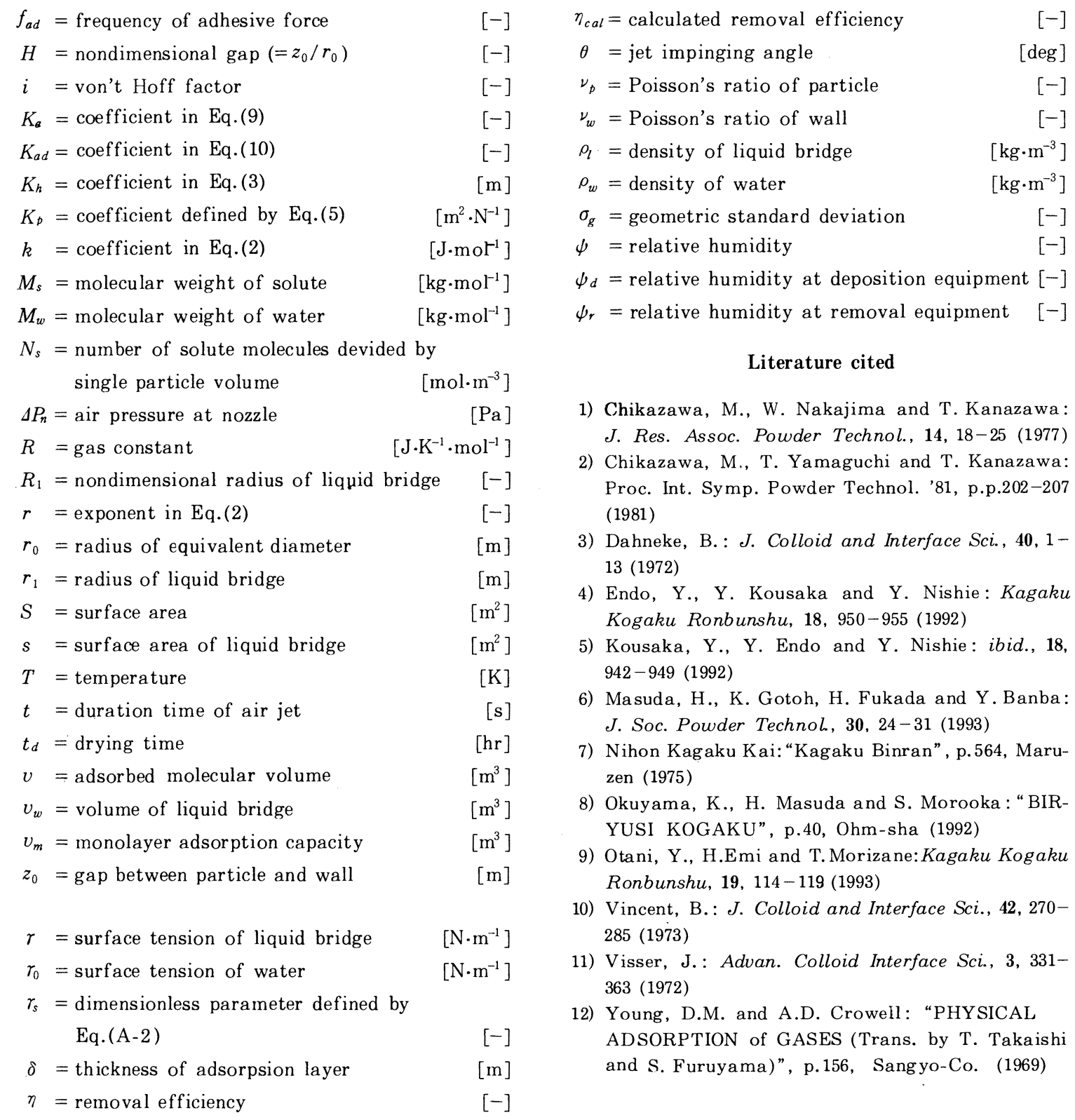




\title{
The Effect of Humidity on the Removal of Fine Particles on a Solid Surface Using a High-Speed Air-Jet
}

Kuniaki Gotoh, Syoji Takebe and Hiroaki Masuda

Dept. of Chem. Eng., Kyoto Univ., Kyoto 606-01

\author{
Yoshiji Banba
}

OMRON CO., Kusatsu 525

Key Words : Removal Efficiency, Surface Cleaning, Effect of Humidity, Deposited Particles, Fine Particles, High-Speed Air Jet

The effect of operating conditions on the removal efficiency of deposited particles using a high-speed air jet was studied with particular attention to the humidity of air surrounding at particle deposition and the air-jet removal. The experimental results showed that the removal efficiency of particles deposited in a low-humidity atmosphere decreased with increasing drying time after the deposition. In the case of deposition under high humidity, the removal efficiency increased at the beginning of drying and decreased rapidly after achieving maximum efficiency. For drying over $80 \mathrm{hrs}$, however, the humidity of surrounding air at the particle deposition did not affect the removal efficiency.

The efficiency also depended on the humidity at the air-jet removal, and achieved maximum value at $67 \%$ relative humidity. Such a variation in removal ef ficiency has been well explained by the change of Hamaker's constant with the adsorbed layerthickness of water molecules and the variation of liquid surface tension with the thickness of liquid bridge. 